\title{
Proposing Publicity Leaving Church Apolitical Piety
}

\author{
Lasarus Umbu Labu Pinyawali ${ }^{1}$, Purwo Santoso ${ }^{2}$, Paulus Sugeng Widjaja ${ }^{3}$ \\ ${ }^{1}$ Doctoral Student of Inter-Religious Studies, Graduate School of Gadjah Mada University and Lecturer at \\ Sumba Christian Church Theological Seminary, Indonesia \\ ${ }^{2}$ Professor of Government Science at Political and Government Study Program, Faculty of Social and Political \\ Sciences, Gadjah Mada University and Lecturer at Nahdlatul Ulama University Yogyakarta, Indonesia \\ ${ }^{3}$ Lecturer at Theology Faculty, Duta Wacana Yogyakarta Christian University and the Inter-Religious Studies \\ Program, Gadjah Mada University Graduate School, Indonesia \\ Email: ${ }^{1}$ lasaru.pinyawali@mail.ugm.ac.id; ${ }^{2}$ psantoso@ugm.ac.id; ${ }^{3}$ pauluswidjaja@staff.ukdw.ac.id
}

\begin{abstract}
This article seeks to release the Church from the false dichotomy of piety vs activeness in political issues, so that church members can optimally actualize piety and public responsibilities simultaneously. Apolitical piety has been running in GKS since its establishment on January 15, 1947, as the Dutch Reformed Church's evangelism legacy. Apolitical piety places the piety only as an individual's internal affair, not covering the public sphere. This discourse is a direct influence of Pietism, which began to develop in Europe in the 16th century. And Pietism itself was present as a response to Secularism, which originated in European society since the end Middle Ages. Like Pietism, Secularism also places the Church/religion and mystical aspects as personal human affairs because it doesn't want state life to be governed by or based on religion. But ideally, I view apolitical piety as the distorted discourse that should be abandoned and embrace new discourse: politics as an integral part of Church piety.
\end{abstract}

Keywords: Apolitical, Piety, Discourse, Secularism, Pietism.

\begin{abstract}
Abstrak: Artikel ini berupaya mengeluarkan Gereja dari dikotomi palsu kesalehan vs keaktivan dalam menggeluti isu politik, sehingga warga gereja, bisa optimal mengaktualisasikan tanggungjawab kesalehan dan publiknya secara bersamaan. Kesalehan apolitis, sudah bergulir di GKS sejak berdirinya pada 15 Januari 1947, sebagai warisan pekabaran Injil Gereja Reformasi Belanda. Kesalahen apolitis menempatkan kesalehan hanya sebagai urusan batiniah individu, tidak mencakup ranah publik. Wacana ini merupakan pengaruh langsung dari Pietisme yang mulai berkembang di Eropa sejak abad 16. Dan Pietisme sendiri hadir sebagai tanggapan terhadap Sekularisme, yang berkembang pada masyarakat Eropa sejak akhir abad pertengahan. Seperti Pietisme, Sekularisme juga menempatkan Gereja/agama serta aspek-aspek mistik, sebagai urusan pribadi manusia, karena tidak menghendaki kehidupan negara-publik, diatur oleh atau berdasarkan agama. Namun secara ideal, saya memandang kesalehan apolitis merupakan wacana menyimpang, yang harus di tinggalkan dan menganut wacana baru politik bagian integral Kesalehan Gereja.
\end{abstract}

Kata Kunci: Apolitik, Kesalehan, Sekularisme, Pietisme

\section{Introduction}

Naturally, human beings, on the one hand, are religious creatures, but another hand, social creatures. From these two human natures, then religion and state were born. Religion is understood to constitute the human expression self as a spiritual being, while politics or state articulation of human nature as a social being. Because religion and state are logical consequences of essence human as religious and social beings, separating religion and politics constitute impossibility. Institutionally can be separated, but both of them always go hand in hand in value and praxis.

The inseparability of religion and state can be seen in sociological discourses of religion. Even religion occupies a significant position in society. Religion has also played a strategic role in building 
community and political order. Emile Durkheim convinces us that religion is society's highest cultural expression in line with this idea. Religion is born from collective society awareness about the sacred. In this context, the sacred doesn't come from the community outside, as understood by world religions generally. Religion here is characterized by worship to the holy and maintaining individual solidarity feel in a group. Between theological and sociological inseparable, if the top part is theology, then the bottom constitutes sociology and vice versa (Horii, 2019).

From sociological discourse, it can be observed that collective consciousness among religious adherents quickly converted into social solidarity, even as political support. This is the point where religious involvement seems politically dangerous. In the name of democracy, mobilization of spiritual solidarity can quickly be processed or applied as the fighting basis for competing over the public office. For example, in General Election for Head the Special Capital Region of Jakarta 2017, clear that Muslims as the majority benefited and mobilized significantly to win certain candidate partners (Sahalatua, Hamid, \& Hikmawan, 2018). At this point relationship between religion and politics becomes problematic.

The discourse suggests maintaining its purity, and religion needs to be separated if not kept away from politics. The eminence of religion has been transformed into religious piety, and at the same time, the religious community quickly escaped itself from political life. In this line of discourse, alienating religious leaders from politics is considered political prestige to maintain holiness. Thus, politics is presented as a betrayal of religion. Remember that in politics, spiritual teachings are easily compromised if unintentionally violated.

Given the hegemonic nature of politics, there are only two options for religious involvement. There is the theocratic system (spiritual state) at one pole in which politics exists as part or only consequence application of religious teachings. A pole of another choice, the secular system (secular state) limits religion only as a private matter. Thus, there is no religious nuance in public/state affairs. The heritage of these two options is equally available. However, social scientists usually tend to study the relationship between religion and state in line agenda of secularization.

Peter L. Berger, for example, starting from an overall secularization perspective in the 1960s, predicted that religion would only be a private matter in the future. But after seeing social reality at the end 20th century and the beginning of the 21 st century, he admits to failure in his predictions. It turns out on the era he intended, religion exactly re-entered and influenced the public sphere very strongly. He said that process of secularization has disappeared. On the other hand, what appears is a desecularization process. In his writing entitled "The De-secularization of the World," he states that the world today is "equally be religious like before". De-secularization is the modernization process that makes people secular and leaves religion on the one hand, and revives the religious spirit and religious symbols. Secularization has become a history child whose existence cannot be underestimated (Berger, 2001). Berger emphasized no reason to think that the world in the 21 st century will be less religious than the world before. The discourse that rejects religion inevitability in contact with politics seems to fail to survive (Hjelm, 2014).

Berger's statement above was confirmed by Jose Casanova and Jurgen Habermas that religion plugbacks its influence in the public sphere. This phenomenon made Casanova say that we are now experiencing "de-privatization." Religion is no longer just a private matter but re-entered and affects the public and political sphere. It is a big mistake to say religion has been buried from the public sphere politics, says Casanova. But according to him, this isn't a modern social structure but only a historical 
choice. This means in the contemporary world, religion and state remain structurally separated, but religion intervenes freely social environment in which it lives (Kippenberg et al., 2013). In a similar tone, Habermas considers that we are already in the post-secular era. The secular post is intended to strengthen religion's role in the public sphere. If in the secular era religion is considered to have left the public sphere and only lives in private space, then in post-secular era, religion has re-entered the public sphere (Possamai, 2017).

This is in line with Talal Asad's findings that religion cannot be separated from politics (State). Institutionally it can, but individually and meaningfully impossible; religious members who are also state citizens will always be involved in state life along with its religious values. Because of that, Asad recommends continuing to reconstruct the position and religious involvement in the life of every modern country (Abdul Majid \& Ahmad Jalaluddin, 2018). Asad argues that religion will have a caring attitude towards a public debate about how the state economy should be run, which the state should fund the scientific project. What broader goals of the national education system should be, then religion becomes an integral part of modern politics. The entry of religion through legitimate way into this debate has resulted in the contemporary hybrid model. As a result, the principle of structural differentiation (that religion, economics, education and science are placed in the autonomous social realm) can no longer be maintained. For Asad, more illogical in secular view, this is happening not only because today religion plays an essential role in the modern world of nations, but also, we caught on wrong category: to choose 'religion' and 'politics'. Yet two are interconnected more deeply than we think (Asad, 2003).

In Indonesia, where religion hasn't been completely separated from politics, the proper mix is needed. If the synthesis of both hasn't been done correctly, it will create high political tension. This is mainly because the state adopts a liberal design, in which political contestation is appointed as the political norm. From the beginning of the 1998 reformation, Indonesian politics have been marked by religious tensions. During the New Order era, religion was almost invisible in the political sphere, ultimately becoming the basis of mobilizing political affiliations to win the political competition. Religion seems to gain strategic momentum to participate in Indonesian politics, both at central and regional levels. As a result, the religious role in Indonesian politics appears out of control, such tsunami whose coming cannot be stopped. This can be seen on almost all stages of politics, both at national and regional levels, religion always present in various ways. For example, on General Election for Head of Special Capital Region at Jakarta, is clear Islam as majority significantly involved and even determined the victory of certain candidate partners (Sari, 2016). Furthermore, in the process of General Election for Indonesia President and Vice President on April 17, 2019, Islam return showed its influence, so that became a political strategy target to determine victory (Saputro, 2018).

The thinking framework presented in the literature review above emphasizes that piety and politics go together and don't justify an apolitical approach in practising commitment and faith or religious values. However, "Gereja Kristen Sumba-GKS" (Sumba Christian Church) precisely practices this apolitical approach. They consider it as a piety path (apolitical piety). For example, in every General Election period, GKS will take a neutral stance or be silent (Dawa, 2020). Therefore, the research question: how is the discourse on GKS apolitical piety going on? The purpose of this study is to find a suitable model or way so that GKS's holiness and its involvement in politics can go together. On the one hand, GKS's purity is maintained, and at the same time, doesn't stop GKS involvement in politics. Affirming political purity is a good strategy because religious leaders neglect ordinary adherents quickly drawn into pragmatism. As a result, people who live righteousness and cling to their religious 
commitments are easily trapped in the attitude of "apolitical piety". This is a kind of political pragmatism in community and religious thought. Simply put, the responsibility of being a piety man is behaving politically neutral, if not apathetic. The apolitical piety discourse seems reasonable in terms of religious worthiness but raises serious questions? Who is then responsible for handling political crimes, given the powerlessness of ordinary adherents to control their political, ethical behaviors? Affirmation of political piety can also help political notions such democracy for enforced among religious people who are full of seriousness in religion (Rantung, 2017).

\section{Method}

The research approach used in this research is qualitative. Because the truth or meaning to be explored in this research tend to analysis and interpretation. While the research method used in this research is discourse analysis. Discourse analysis is part of qualitative approach, that main focus is exploring the ideas or meanings behind words and sentences, both in the form of expressions and writing. Discourse analysis is similar to the interpretative design method, which emphasizes how to explore the meaning behind the text (Zaluchu, 2020). The object of data in discourse analysis is text (written or spoken). The principle in discourse research is that by understanding the meaning text behind, the empirical context considered have been understood. Because according to discourse research, the meaning or ideology built by text (words and sentences) comes from context. So that by understanding the meaning text behind, the context has also been understood (Jørgensen \& Phillips, 2002). To get data, researcher conducted in-depth interviews, searched and collected number of documents, both in the form of books, papers, journals, reports, conversations and meeting decisions, as well as various other related documents.

\section{Apolitical Piety: Sumba Christian Church}

Since establishment of GKS on January 15, 1947, has adhered principle that politics/ state isn't its affairs: "Geredja dan Negara mempunyai dasar dan tudjuan jang berbeda setjara azas, yaitu Geredja terpanggil untuk membangunkan keradjaan Allah dan Negara terpanggil untuk membangunkan keradjaan duniawi , " (Natar, 2017). It is translated approximately like that: The Church and State have different principles and objectives, namely Church is called to build God's kingdom, and State is called to construct worldly kingdom." This principle adopted by GKS shows that, first, Church and State aren't only different and separated and did not interfere. Second, GKS also as if contradict duties of both in quality, church takes care of holy things (God's Kingdom) while state deals with dirty/evil (worldly) aspects. Because usually from Christian perspective, "worldly" is understood as personification of darkness or things that are contrary God's will. In addition, as I have observed and experienced in research reality, members of GKS congregation and most Pastors and other leadership elements on congregation still view politics as something dirty. With ecclesiastical discourse/perspective like this, conscious or not, GKS will automatically be led to see that avoiding and staying away from politics is piety path (apolitical piety). In other words, politics isn't included in the road of GKS's piety.

Therefore, it isn't surprising if GKS ignores every election that took place in Sumba. When Election period comes to elect regional, provincial, and national public officials, GKS will always remain silent, or term commonly used by GKS is neutral. This means as institution GKS will not do anything, apart from allowing its members involved without assistance and pasture, how defend or apply their piety on election process. In other words, there wasn't effort made by GKS, for its members kept their piety from 
various dirty political influences/temptations so that they could undergo general election correctly and fairly.

In interviews with several pastors/reverent older generation, leaders of GKS Synod currently and former, emphasized that this principle is legacy from evangelism Dutch Calvinist Church. As result Gospel preaching of Dutch Calvinist Church, GKS automatically became Calvinist and followed church's principles and practices have been inherited. Indeed, in the era 2000s and over, GKS began change little, but was limited reading / conveying pastoral voice to congregation, through Sunday worship. This pastoral voice or moral advice is usually made by Communion of Churches in Indonesia (Persekutuan Gereja-gereja di Indonesia-PGI), then distributed to all PGI's member churches, including GKS. This moral advice then conveyed by GKS to all congregations in scope its ministry (Dingu \& Samani, Interview, 1 Juni 2020).

The apolitical piety discourse influence above isn't felt only on election contexts but also in politics on the whole. When I read entire discussion and decision of GKS Synod Assembly from its inception (1947) until present, there are hardly any theological-political considerations. In my findings, there are more or less only three political-theological points that discussed and decided upon. Discussions and decisions made on these themes cannot be separated from influence of discourse apolitical piety. Three theological-political topics are meant: First, how GKS's attitude toward Communist Party. This theme only discussed in two meetings, namely at 10th (1956) and 11th (1957) synod meetings. The GKS's decision was reject Communist Party, because it rejected God's existence, denied Jesus Christ as Lord and Savior and hated all religions including Christian (Natar, 2017).

Two, relationship with local government in Sumba. In early periods since its establishment 19471966, GKS highly restricted its relations with government, namely only made contact with certain agencies, if be needed in service, for example attempt to eradicate snails were endemic at the time. GKS also very strictly prohibits congregations for asking assistance in any form to state/government, because church and state have different principles and goals. The church is called to establish God's kingdom, while state is called to establish earthly kingdom. Therefore, church should build God's Kingdom based its own strength, because Jesus Christ Himself leads His church. If there is donation from state, only actual gifts will accepted (Natar, 2017).

However, the next traveling, relationship with government has increasingly liquefied. For example, meeting of GKS-21 Synod in Ede - Milla Ate, July 26, 1967, for the first time two district governments (West Sumba \& East Sumba) were invited to attend and give opening speech ceremony. This condition continues until now, even invitation has increased of provincial and national level governments. At present, invitations and presence government as well as giving opening speech in various ecclesiastical events have become common within GKS (Natar, 2017). Gradually, GKS began habitual receiving assistance from government, even intentionally asking assistance government, for various purposes. For example, since decision of 36th Synod Meeting 2006 at Kahembi Kalelangu Congregation, GKS built cooperation with East Sumba district Government, through "Inisiatif Masyarakat Setempat"-IMS (Local Community Initiative program), in order empower economy of congregation members. According its name IMS, this program was born based congregations initiative and request in East Sumba Regency. The funds are prepared by East Sumba Regency Government and its administrators are congregations in East Sumba Regency. In the same space time, something like that also happened at congregations in West Sumba Regency (Taka, 2017). 
Three, whether Pastors/Reverent can be involved in nominating and becoming public officials (legislative \& executive). This theme more often be discussion, especially since 31 st synod's meeting at Tanarara Congregation, 1982 (Natar, 2017). The discussion this subject is still ongoing today, because number of Pastors want become public officials (legislative and executive) increased. Discussions on this theme always present hot debates, between those who agree and disagree, Pastors is involved be candidate and public official. The choice agrees or not also determined by discourse or theologicalpolitical perspective their refer.

Largely the synod's attendees of meeting seem very influenced by view that politics isn't church's business, and is something dirty and should be shunned. Based this point of view, they reject Pastors being involved becomes candidate and public officials. For them, basically politics is dirty, or identical with crime. Therefore, make it clean by presence Pastors, it is impossible, conversely, pastor's holy office will disgraced. Otherwise, small number of synod's attendees of meeting, especially among younger generation, who saw politics as something good, and constitute integral part church's responsibility, agreed of Pastors were involved in nominating and becoming public officials. Even though its fact that politics is dirty, for them, Pastor's presence will help to enlighten and clean up politics (Observation).

At grass root level, their response about this was generally uniform, namely they strongly disagreed with Pastors involved in politics. This is because apolitical piety discourse deeply planted in their subconscious mind, making them view of politics as something dirty, while church and Pastors office is holy. The two of them were very opposed to each other, and therefore Pastor very unworthy enter politics. Pastor's involvement in politics will only pollute their holy office. If there Pastors who are involved in politics (for example, become legislative members), congregation members also very uncomfortable feel (Interview \& Observation).

Where did apolitical piety discourse come from? More or less there three polarizations of answers that I got into research field. Among ordinary congregation's members, they said that basically politics is dirty, because politics constitute worldly affair. Meanwhile, among Pastors, especially older generation, synod leaders both former and currently, answered: This has been legacy evangelism from Dutch church (Interview \& Observation). Whereas, among academics (lecturer Pastors), among others, Pastor A. A. Yewangoe, explained constitute Pietism legacy, which had influenced Dutch Church and its missionaries, who sent to preach gospel in Indonesia generally and Sumba particularly ( Yewangoe, Interview, 25 Juli 2020).

\section{Traces of Secularism}

The apolitical piety discourse adhered by GKS contradicts with Christian Bible teachings and Calvin's doctrine on relationship between Church and State. From point of view biblical teaching, it seems responsibility implementation of Church piety is limitless. This limitless implementation of church piety, indicates that Church don't exclude politics in embodying piety discourse. In other words, presenting Church piety in politics is inevitability. The piety in church take place all the time, is addressed all mankind (Matthew 28: 19-20), includes other creatures and universe (Mark 16:15), without exception. Generally, implementation piety includes two things: keep/apply and spread. Keep piety compatible with meaning of text in Matthew 5: 13-16, where Christians are likened the earth salt and world light. The most common function of salt is give delicious taste, so Christians life attitude in this world, whenever and wherever (include on politics) should be meaningful or blessings, bring peace and 
prosperity to all human being, even other creatures and universe (Bambangan, 2020). Meanwhile, light has function illuminate or be bright to others. This means Christians should be role models for many people, whenever and wherever, in living piety values ( Ugochukwu \& Ikechukwu, 2021).

Likewise, when Christians there are in political context, piety values should be lived and become spirit that drives their political journey or activity. They should be political role model for all citizens. So that with their presence on politics, in addition maintaining and strengthening piety values state and nation, will also make political life more be civilized and bring prosperity to all citizens. The presence of Christians like that way will give very valuable contribution toward life order nation and state that increasingly civilized ( Ugochukwu \& Ikechukwu, 2021).

Apart of living, Christians are also given responsibility spread / voice and teach piety values to others and even all creatures, including politics (Psalm 9:11, Mark 16:15, Acts 5:20, I Timothy 4: 11, II Timothy 4: 2, Titus 2: 1). This meant so that Christian piety values are understood, recognized and lived out by others in their respective contexts. In political context, for example, Christians have to speak out religious or piety values, both to individual and institution. So that political people and their institutions are enlightened, and protected from dirty / evil political behavior (black politics). For example, corrupt behavior or vote buying on General Elections, which are endemic and deeply rooted in Indonesian political culture. Here Church is obliged to speak out toward state and teach its followers/adherents that these political behavior should eliminated because contrary to Christian piety and noble values of national life in Indonesia (Jebadu, 2017).

Even John Calvin's teachings, which are adhered by GKS until current, also didn't teach Church to view politics as something dirty and stay away from there. Calvin didn't want state without church connection (secular state), and church without state connection (individual inner piety). He only wants Church and State be autonomous institutionally and in conducting their respective duties. However, in implementation their respective duties, remain connected to each other, influence and even interfere, but within certain limited. For Calvin, State and Church are two governments that come from God, with their respective duties, but still connected each other. The state deals with physical or worldly matters that interim, such law, economy, security, fighting crime, and etcetera. Meanwhile, Church deals with spiritual / inner and eternal life - heavenly matters, such worship, prayer, fasting, meditation, preaching God's Word, teaching truth and justice that sourced of Bible and etcetera (Calvijn, MacNeill, \& Battles, 1960a).

The connectivity the two: Church should be inspiration source of truth and justice values in administration State life. Therefore, task Church towards State is always conveying its critical prophetic voice to government, and teach them of truth and justice values that originated of Bible. On other hand, the State, in this case government, is obliged provide protection and comfort to the Church and other religion, to run spiritual/inner affairs related eternal/heavenly life, as described above. This is based on Calvin's understanding and belief that State also God's grace (not only church). and therefore, should be run in truth and justice spirit. In this case, Calvin didn't mean the presence of theocratic state, or Christian teachings became State rule (Kolimon, 2016), but only as source of inspiration and ethical values in formulating and implementing various state policies. In this way of thinking, Calvin also really hopes that government or state officials can carry out their duties in piety manner-be fair, honest and etcetera (Calvijn, MacNeill, \& Battles, 1960b).

Apart that, socially and politically, Church's members are automatically citizens. This means that Church keep have social responsibility for good and advancement state life. Therefore, from this socio- 
political perspective, isn't justified if Church didn't place State / politics as integral part in run piety discourse. State is part of objective manifesting God's Kingdom values, such truth, honesty, justice, and peace (Ngelow, 2014). Thus, based three perspectives above, apolitical piety discourse actually didn't suitable lived by GKS, or ideally can said, that apolitical piety is distorted discourse, which should avoided/shunned by Church.

If traced historically, GKS's apolitical piety discourse is legacy Dutch Calvinist Church (Gereformeerde Kerken in Nederlands - GKN), as carrier Gospel in Sumba, since 1892 and founder GKS 15 January 1947, and continues of cooperative relationship until now (Wellem, 2004). Although GKS is Calvinist, apolitical piety teaching originated Pietism, not Calvinism. Because GKN, who came preach Gospel in Sumba at the time, was already influenced by Pietism. John Calvin only taught that separation between Church and State didn't absolute. This means that Church and State are autonomous institutionally and in their respective duties but still interact and support each other. For example, Church also struggles presence of piety in administration state life, and other hand, state guarantees freedom and security of Church in running its spiritual life. In contrast to Pietism, which considers politics as something dirty and didn't Church business, as well as should be shunned to maintain piety (absolute separation).

Pietism places the piety discourse as individual inner affair, not public-state affair. In other words, route Church's piety doesn't include state or social - public, only on inner-individual realm. Pietism began appear in Western Europe at the end of eighteenth century, and became very important revival movement, especially in Germany and Netherlands. Pietism is spiritual ideology or stream in Lutheran and Calvinist Church that focuses on personal inner piety. In general, Pietism was reaction toward influence of secularism which increasingly strong in church life and European society at the time (Berkhof \& Enklaar, 1986).

Such as Pietism, secularism also aims to shift church (piety) from State realm- public to private realm. If the essence the church is piety matter, then that want shift by secularism from State - public sphere to private sphere, not only church as institution but also religious/piety values. If Pietism makes piety as individual inner affair, in order to maintain church piety, then Secularism makes independent thinking of individual human beings, as way to distance oneself from the influence of Church piety (Zaluchu, 2018).

The emergence and development of secularism is reaction against very strong domination Church, in whole life order European society throughout Middle Ages. It is common knowledge that throughout medieval period (Catholic) Church united with State power (Roman empire and kingdoms) in European society generally (Zaluchu, 2018). In early century AD Christ's followers (Christianity), were only seen as a sect/splinter group, both by adherents of Jewish religion and Roman Empire. In like that claims, they experienced torture and even death, as part of Roman Empire's attempt systematically eradicate them. In such conditions, making Christianity at the time view politics in negative perspective - evil and must be shunned (Olla, 2014).

However, it was different, when Emperor Constantine Great ruled (the West) and converted to Christianity in 312. Since that Christians are no longer be state fugitives but have turned into close friends, even receiving special treatment. If previously they suffered in poverty, now they are familiar with power and luxury (materialistic). Marking this relationship, he and his brother-in-law Licinius, who ruled the Eastern empire, produced "Edik Milano," in 213. It contained that church got complete freedom, even all church property confiscated by state should be returned or paid. Not only that, in 380, 
Emperor Theodosius Great made Christianity as State religion (Catholic) and obliged all Roman Empire's citizens only adhere Christianity/Catholicism. Thus, church was previously marginalized outside of Palace now becomes the occupants Palace and also holds power. Not only participating but also being holder and controller of power - here power is synonymous with Christianity (Christian State). The Church officials and Roman Emperors and kings of European society exercised power together, in spirit of symbiotic mutualism. The empire is getting stronger because got divine legitimacy, on other hand, Church can enjoy abundance of wealth and easiness in preaching and spreading Christianity (Olla, 2014).

The previous Church's negative view towards State has now changed, State is seen God's grace and means of salvation. Power is used as way for preach and spreads Christian faith. Christianity, which previously is excommunicated and persecuted now become medium of honor and power. Christians appear as defenders of Caesar and kings. Slowly but surely, Church became single ruler over entire life order of European society, throughout Middle Ages. Christian teachings become life references, both in form thoughts, values, and various national regulations. But at the same time, Christianity has lost its critical prophetic voice even only become tools of legitimizing power and all its policies, including evil. Church is involved and even becomes performer of injustice, oppression, war, corruption, and various other crimes of power. Unmitigated, Church easily legitimized that thing as acts of piety. For example, war that aimed to eradicate State's enemies from outside is legitimized as holy war/crusade. In short, can be said, close ties Church with power throughout Middle Ages, caused Church almost losing its conscience, and various Church rites, nothing more than routine and formalism (Olla, 2014).

Scientifically, Middle Ages are known as theology age or Christian philosophy, because very strong domination Church at the time, humanist/secular philosophy and other sciences completely paralyzed. As result, life of European society on all segments has become stagnant, no significant progress achieved in all life areas, especially on fields of science/technology and materials. Teachings and various decisions of Church (Christian philosophy), should be accepted as single truth in this era. Those who do philosophy are only Pastors, clergy, or church officials (Tjahjadi, 2004).

Such reaction and resistance to Church's power and domination that highly strong in socio-politics and science, emerge efforts secular. In 14th and 15th centuries, secularism/humanist thinkers began trace and anchor their thoughts at ancient Greek and Roman cultures, which had been buried by very strong church tradition during Middle Ages (Renaissance). In this search, they found important values, so that European society could get out from stagnant condition of Middle Ages and achieve various advances on future. The values were found: Respect toward world here, respect and recognition to dignity and ability of human ratio as an individual. Since Renaissance, human ratio ability has been highly respected and considered capable of determining everything, without depending of Church traditions, mystics, God's revelations, and holy texts of Bible. The belief on subjective ability (ratio) of humans also impacts at interpretation of biblical texts. Interpretation of biblical texts began be carried rationallyindividualistic manner. Martin Luther's teaching, that Bible can be interpreted own and each person could become priest for himself, actually constitute direct influence of Renaissance humanist philosophy. The theory of two kingdoms/governments (separation Church and State) from Luther and Calvin, also cannot be separated from influence of Renaissance era. Because at this time, with belief of human capabilities, humanists developed state secularization system, namely separating State from highly strong grip of medieval Church (Hardiman, 2004). 
The secularization project (removing from Church, revelation, and holy texts) in all life areas, during Renaissance, continued until enlightenment century (German: Aufklarung). The enlightenment era was famous with slogan "Cogito Ergo Sum" (I think then I exist - by Descartes), and "Sapere Aude" (brave to think own). In this era (17th \& 18 th century), ability of human reason got true authority. Ability of human ratio are truly considered independent, or totally disengaged from supernatural authority (church traditions, revelations, and holy texts). The human ratio is believed able to bring progress for European society in all life aspects. The spirit breaks away totally from supernatural powers or church began be held, in various fields of European life society. In socio-political sphere, for example, impact directly visible, such English revolution in 1668 and French revolution 1789. British Revolution was known as: "The Glorious Revolution" which caused King James II abdicate of throne. In addition, William should also recognize rights of Parliament and making laws and Government Regulations, so that Britain became first country, have constitution, in modern sense, as be poured in "The Declaration of Human Rights"-January 1689 (Tjahjadi, 2004).

The revolution of secularism/liberalism in France took place radically. It is more anti-Church movement. Voltaire (1694-1779), for example, called Church eradication: "Ecrasez Linfame" (destroy bad). As part of anti-Church movement in France, Jesuit fathers were expelled in 1764 (while in Portugal took place in 1759). The Jesuits with their teaching: "Sentire cum ecclesia" (Co-understanding with Church), were accused as henchmen of Pope and conservatives, wanted defend Church and considered be obstacles of modern/secular movement. In 1773, Pope Clement XIV was forced to close down this Jesuit order. Furthermore, to mark this secular movement, France, was established a ratio statue in Notre Dame cathedral in 1793 (Tjahjadi, 2004). In addition, theology was separated from philosophy and social science from philosophy (Hardiman, 2004).

The radical secular revolutionary movement in France then spread and influenced all European society, and gradually countries in Europe began adopt secular state system. Countries with theocracy system (Church Power), increasingly abandoned and shifted to democratic system. With this system, moral values and state administrative rules no longer originated the Church, but from secular or humanist thoughts/philosophies. In addition, power is no longer centered on person (King or Emperor), but spread across to various state institutions, and all people participate in running power through elections. The single power that determined or appointed by God was erased, and replaced by multiple powers, which determined/chosen by many people (all citizens). As result, Church's domination and influence on politics/state, in fact, in many cases, has become nothing (Olla, 2014).

In response this condition, Church has negative attitude and antipathy towards politics and refuses to participate or involved in administration state life. Marking this Church's negative attitude, Pope Pius IX, in 1874, issued decree "non expedit" or inappropriate/good, which contained exclamation for all Catholics in Italy didn't take part on general elections or in political life of Italian state. Pope Pius also censure democratic principles in "Syllabus Errorum" (List of Errors) on 1864. This anti-political attitude then spread in Churches throughout European countries at the time. With this discourse, Christians are led to view politics not Church affair, and piety (spiritual life) only personal matter (not state affair). Slowly but surely, eventually, Church or religion in Europe was ripped off from state life system and only became private matter. This system was later followed by Turkey (Islamic State) and United States (Olla, 2014).

Such negative attitudes towards politics also emerged in Calvinist Church, was showed by Pietism (piety only inner individual matter). They, therefore, wanted absolute separation of Church and State. 
According to Pietism, this was important in order to break/disconnect the role and authority of kings and nobles, who ruled church arbitrarily. This teaching actually is continuation by Luther and Calvin's teaching but becomes more radical, following Secularism attitude which requires absolute separation of Church and State. Because at empirical level, both Luther and Calvin' teachings, have not been fully realized, both in Lutheran and Calvinist churches. In Netherlands, for example, Calvinist Church not yet been separated from state/kingdom, so that Church life still under control of kings and nobles. For Pietism, piety has no correlation with state-political life. Politics then is considered as dirty/unclean area and should avoided. Participation in politics by itself is considered as dirty/evil act (Hale, 1994).

\section{Politics Integral Section of Church Piety}

If above GKS places politics didn't include in administration of Church piety, here I propose that politics be integral part of Church piety journey. The first reason, if entire universe and everything constitute God's creation, then politics cannot be excluded, and therefore politics should be run in God's will (piety). Second, in Book of Psalms 103:19, be said that God's Kingdom or His Powers takes place everywhere (without limits). That means piety as modus operandi of administration His power, also without limits, takes place anytime and anywhere. Third, in Romans 13:1-7, increasingly narrowed and be confirmed that State comes from God and government is God's servant, to bring goodness (piety) all citizens, including Christians.

Departing of three theological bases above, there is no reason for Church to remove politics from piety map or performance God's will. Moreover, socially and politically, the Church, especially individually, is integral part State. Church's members in a country, are also citizens. In such double status position, connectivity of Christian piety values, in State life, is increasingly inevitability. Thus, in principle, both theological and socio-political, implementation of piety in State life become very relevant. Furthermore, only clarify how this role is run by Church. In other words, what is the Church piety role in politics?

First, in order maintain its independence, as moral politics fighter, not power politics, Church doesn't need become a political party to compete gain of power or become government. Medieval experience taught, when Church took over of power and even became single ruler, Church lost its distinctiveness as light of truth and justice. The Church's critical prophetic voice is no longer heard at all. Even Church legitimizes all things including political crimes, such injustice as God's will (truth).

Second, in accordance with its position as moral political fighter, Church should be role model and ethical values source (e.g., justice, equality, etc.), both at level of policy formulation and in state life practice. This suitable with Jesus's political spirit which prioritizes repentance or new life culture, both at values level or discourse and action (Widjaja, 2014). Third, Church has to play its critical function and control over State, through delivery its prophetic critical voice. As God's tongue, Church is obliged constantly criticize various deviations of justice and truth in State life. For example, in General Election, if there are indications, moreover, has been deviations from justice principle, then Church obliged convey its prophetic critical voice.

Fourth, educating and assisting Church's members to live the right political behavior. Make Church's members as obedient and responsible citizens, bring peace and prosperity to all citizens. For example, in General Elections context, Church needs prepare and assisting its members, both voters and public office candidates, to undergo general elections based on democratic principles. In Indonesian context it is known as "Luber"(Direct, public, free and secret) and "Jurdil" (Honest and Fair). By 
carrying out this educational role, Church is actually helping prepare civilized political culture. In addition, it is also constituted critique in action form against dirty political culture, which maybe it's going on. For example, corruption culture that is deeply rooted in Indonesian political culture, if Church succeeds in presenting clean culture of corruption, through its members, then Church has offered new political culture in Indonesia.

\section{Conclusion}

GKS's apolitical piety discourse originates Pietism, namely a discourse that limits Church piety only inner-individual affair, not public-state affair. However, born of Pietism in European history stage was response toward Secularism discourse, which had strengthened in European society, from late Middle Ages until modern times. Secularism is discourse that throws Church or religion from public-state sphere into private sphere. Secularism wishes public-state life be managed based secular-humanist understanding and values, free from influence and interference of Church or supernatural aspects. The presence of secularism is also constituted impact domination of Church power (Catholic), in all life areas, during Middle Ages.

Based perspective of Biblical teachings and Calvin's doctrine, as well as Church social responsibility, apolitical piety discourse could not maintain by GKS and Church generally. As feedback to this apolitical piety discourse, GKS and Church generally have to make politics as integral part of Church piety. In this context, there are four roles can be played by Church: First, in order maintain its independence, as moral politics fighter, not power political, Church doesn't need become political party to compete of power or become government. Two, in accordance with its position as moral politics fighter, Church should become source of ethical values (for example justice, equality, etc.), both at policy formulation level and praxis of state life. Three, Church should play its critical function and control over State, through delivery its prophetic critical voice. Four, educating and assisting Church's members to run correct political behavior. Make Church's member as obedient and responsible citizens, bring peace and prosperity to all citizens.

\section{References}

Majid, A. A., \& Jalaluddin, D. Q. A. (2018). The Conflicts between the Secular and the Religious in Tahmima Anam's The Good Muslim. GEMA Online Journal of Language Studies, 18(4), 2641. https://doi.org/10.17576/gema-2018-1804-03

Asad, T. (2003). Formations of the secular: Christianity, Islam, modernity. Stanford, Calif: Stanford University Press.

Bambangan, M. (2020). IMPLEMENTASI MENJADI GARAM BAGI DUNIA MENURUT MATIUS 5:13. Phronesis: Jurnal Teologi dan Misi, 2(1), 24-32. https://doi.org/10.47457/phr.v2i1.30

Berger, P. L. (2001). The Desecularization of the World: Resurgent Religion and World Politics. 11.

Berkhof, H., \& Enklaar, I. H. (1986). Sejarah gereja. Jakarta: BPK Gunung Mulia.

Budi Hardiman, F. (2004). Filsafat modern: Dari Machiavelli sampai Nietzsche: suatu pengantar dengan teks dan gambar. Jakarta: Gramedia Pustaka Utama.

Calvijn, J., MacNeill, J. T., \& Battles, F. L. (1960a). Institutes of the Christian religion: In two volumes. Philadelphia; London: The Westminster Press ; SCM.

Calvijn, J., MacNeill, J. T., \& Battles, F. L. (1960b). Institutes of the Christian religion: In two volumes. Philadelphia; London: The Westminster Press ; SCM. 
Dingu, D. U., \& Samani, A. D. (2020, Juni 1). Church Piety Political in GKS (Christian Church of Sumba).

Hale, L. (1994). Jujur terhadap pietisme: Menilai kembali reputasi pietisme dalam gereja-gereja Indonesia (Cet. 2). Jakarta: BPK Gunung Mulia.

Hjelm, T. (2014). Understanding the New Visibility of Religion. Journal of Religion in Europe, 7(3-4), 203-222. https://doi.org/10.1163/18748929-00704002

Horii, M. (2019). Historicizing the category of "religion" in sociological theories: Max Weber and Emile Durkheim. Critical Research on Religion, 7(1), 24-37. https://doi.org/10.1177/2050303218800369

Ijeudo Nnamdi Ugochukwu, \& Nnadi Christian Ikechukwu. (2021). Matthew 5:13-16 and Political Leadership in Contemporary Nigeria. Journal of US-China Public Administration, 18(1), 27 37. https://doi.org/10.17265/1548-6591/2021.01.004

Jebadu, A. (2017). Dimensi Politik dari Misi Pembebasan Gereja bagi Orang Miskin dan Pemeliharaan Alam Ciptaan. Jurnal Teologi, 6(2), 167-186. https://doi.org/10.24071/jt.v6i2.1001

Jørgensen, M., \& Phillips, L. (2002). Discourse Analysis as Theory and Method. 6 Bonhill Street, London England EC2A 4PU United Kingdom: SAGE Publications Ltd. https://doi.org/10.4135/9781849208871

Kolimon, M. (2016). Yohanes Calvin: Politik, Jabatan Gerejawi, dan Relevansinya bagi Gereja Masa Kini. Jurnal Ledalero, 15(2), 258-273. https://doi.org/10.31385/j1.v15i2.44.258-273

Lere Dawa, M. D. (2020). MENYOAL SIKAP GEREJA TERHADAP POLITIK. SOLA GRATIA: Jurnal Teologi Biblika dan Praktika, 3(2). https://doi.org/10.47596/solagratia.v3i2.40

Natar, A. N. (2017). Membangung Rumah Allah: Gereja Kristen Dulu, Kini, dan Esok. Yogyakarta: Yayasan Taman Pustaka Kristen Indonesia.

Ngelow, Z. J. (2014). Turut Membina Indonesia Sebagai Rumah Bersama-Peran Gereja Dalam Politik Di Indonesia. Jurnal Jaffray, 12(2), 213-234. https://doi.org/10.25278/jj71.v12i2.16

Olla, P. Y. (2014). Spiritualitas politik: Kesucian politik dalam perspektif Kristiani. Jakarta: PT Gramedia Pusataka Utama.

Possamai, A. (2017). Post-secularism in multiple modernities. Journal of Sociology, 53(4), 822-835. https://doi.org/10.1177/1440783317743830

Rantung, D. A. (2017). PENDIDIKAN AGAMA KRISTEN DAN POLITIK DALAM KEHIDUPAN MASYARAKAT MAJEMUK DI INDONESIA. Jurnal Shanan, 1(2), 58-73. https://doi.org/10.33541/shanan.v1i2.1492

Sahalatua, A. P., Hamid, A., \& Hikmawan, D. (2018). Politik Identitas dalam Pemilihan Kepala Daerah (Studi Kasus pada Pemilihan Gubernur DKI Jakarta Periode 2017-2022).

Saputro, A. (2018). AGAMA DAN NEGARA: POLITIK IDENTITAS MENUJU PILPRES 2019. ASKETIK, 2(2), 111-120. https://doi.org/10.30762/ask.v2i2.912

Sari, E. (2016). Kebangkitan Politik Identitas Islam Pada Arena Pemilihan Gubernur Jakarta. Kritis: Jurnal Ilmu Sosial dan Politik Universitas Hasanuddin 2(2), 145-156. http://journal.unhas.ac.id/index.php/kritis

Taka, P. Z. (2017). Gereja Kristen Sumba Dan Masalah Kemiskinan. Dalam A. N. Natar (Ed.), Membangun Rumah Allah: Gereja Kristen Sumba Dulu, Kini, dan Esok Yogyakarta.

Tjahjadi, S. P. L. (2004). Petualangan Intelektual: Konfrontasi Dengan Para Filsuf Dari Zaman Yunani Hingga Zaman Modern. Yogyakarta: KANISIUS. 
Wellem, F. D. (2004). Injil dan marapu: Suatu studi historis-teologis tentang perjumpaan Injil dengan masyarakat Sumba pada periode 1876-1990 (Cet. 1). Jakarta, Ind. [i.e. Indonesia]: BPK Gunung Mulia.

Widjaja, P. S. (2014). PARTISIPASI KRISTIANI DALAM POLITIK DI INDONESIA: Antara Mitos, Realita, dan Politik Yesus. Gema Teologi, 38(2), 123-142.

Yewangoe, A. A. (2020, Juli 25). Church Piety Political in GKS (Christian Church Of Sumba).

Zaluchu, S. E. (2018). Mengkritisi Teologi Sekularisasi. Kurios, 4(1), 26-38. https://doi.org/10.30995/kur.v4i1.31

Zaluchu, S. E. (2020). Strategi Penelitian Kualitatif dan Kuantitatif Di Dalam Penelitian Agama. Evangelikal: Jurnal Teologi Injili dan Pembinaan Warga Jemaat, 4(1), 28-38. https://doi.org/10.46445/ejti.v4i1.167 